\title{
A COMPREHENSIVE STUDY ON THE SEASONALITY OF GREEK EQUITY FUNDS PERFORMANCE
}

\author{
GERASIMOS G. ROMPOTIS \\ Senior Auditor-KPMG Greece \\ Researcher-National and Kapodistrian University of Athens, Greece
}

\begin{abstract}
This paper searches for seasonality patterns in performance of Greek equity mutual funds during the period 2002-2005. Four types of seasonality are assessed: day-of-the week effect, monthly effect, half-monthly effect and holidays' effect. Results reveal a negative Monday effect and a positive Friday effect. Monday returns are also more volatile than the other day-of-the-week returns. Furthermore, the paper demonstrates that the well- known January effect does not apply to Greek equity funds while performance is not affected by any other monthly impact either. However, a half-monthly effect is revealed, namely returns during the first half of each month exceed these in the second half. Finally, a positive holiday effect on returns is found in the week after Easter, August 15th and Christmas.
\end{abstract}

Keywords: Seasonality, Mutual Funds, Day-of-the-week effect, Monthly effect, Half-Monthly effect, Holidays effect

JEL classification: G-14, G-15

Corresponding address: 25, Ypsilantou Street, 12131 Peristeri, Athens, Greeece

e-mail: grompotis@kpmg.gr 


\section{Introduction}

This paper searches for seasonal patterns in performance of Greek equity mutual funds. In general, seasonality provides investors with opportunities to gain abnormal returns in spite of the efficient capital markets hypothesis, which assumes that there are no persistent chances for investors to beat the market and gain returns above the average market returns as new information about stocks is rapidly reflected in their prices.

There are statistical data that verify the existence of seasonal patterns in stock returns. For instance, Dancy (2007) reports that if an individual investor invested $\$ 1,000$ in the S\&P 500 index from November 1st to April 30th every year from 1950 to 2006 - the "winter season" - and held cash in their account for the rest of the year, the account would be worth $\$ 38,700$ before tax. At the same time, if the investor had invested the $\$ 1,000$ in the same index from May 1st to October 31st — the "summer season" - and held cash in their account for the rest of the year, the account would be worth $\$ 916$ before tax.

The literature has shown that returns in the Greek stock market are subject to significant seasonal effects. Alexakis and Xanthakis (1995) use an aggregate index that includes all the stocks listed on the Greek stock market to examine the dayof-the-week effect during the period spanning January 1985 to February 1994. The findings show that returns are high on Fridays and negative on Tuesdays. Mills et al. (2000) investigate the day-of-the-week-effect using both market indexes and individual stocks and verify the findings of Alexakis and Xanthakis (1995). Returns are high on Fridays and low or negative on Tuesdays and Wednesdays. Coutts et al. (2000) examine seasonality during the period ranging from October 1986 to August 1996. The authors consider four major industry indices (General, Banking, Insurance and Leasing) and find a Friday effect (high returns) that applies to the General and Banking sector indices but not to Insurance and Leasing indices. In addition, they find that the January effect exists for the indices and becomes stronger through time. Kenourgios and Samitas (2008) also show that the day-of-the-week effect applies to stock returns and volatilities in the Greek market over the period 1995-2000 but this pattern weakens in the period 2001-2005 (after Greece's entry into the euro-zone). However, Tsangarakis (2007) rejects the existence of the day-of-the-week effects in the Greek stock market. He examines the period 1981 to 2002 and finds no statistical evidence for systematic patterns across the days of the week suggesting that investors may have improved risk pricing. Finally, Floros (2008) searches for calendar effects on returns of stocks listed on the Athens Stock Exchange (ASE). He uses data for the period starting on November 26, 1996 and ending on July 12, 2002. Results indicate the non-existence of the January effect. In addition, results provide evidence (but not significant) for a half-monthly effect, namely returns in the first two weeks of a month are higher than those in the last two weeks of the month. 
This paper examines seasonality in stock returns in the Greek market using data from equity mutual funds during the period 2002-2005 while all the studies mentioned above use data from market indices or individual stocks. Another contribution is that we examine simultaneously various types of seasonality while the other studies on the Greek stock market mainly focus on the day-of-the-week effect on returns. In addition, the data we use are more recent than those of other studies (except from the data used by Kenourgios and Samitas (2008)). Finally, our results may help investors to apply exploitable time strategies by investing in Greek equity funds, resulting possibly in a boost to the assets managed by the Greek mutual fund families.

We first search for day-of-the-week effects on performance and find that average returns are negative or very low on Mondays whilst returns are high on Fridays. The Friday effect is consistent with the findings of the previous studies of the Greek stock market. In addition, we find that Monday returns are more volatile in comparison to returns on other days. Furthermore, we demonstrate that the well-known January effect is not a dominant phenomenon in the Greek mutual fund market. The paper provides evidence that the January effect applies to Greek funds' return only in one of the four years of the study period. The results are consistent with those of Floros (2008). Moreover, the paper demonstrates that there is not any other persistent monthly effect on returns of Greek funds. Going further, we provide strong evidence for the existence of a half-month effect. More specifically, we find that, on average, Greek funds' returns are higher during the first half-month for all the years of the study period. However, this finding does not apply to all the single months of each year but applies to the majority of months and the mean terms of all half-monthly returns for the whole period. Finally, we find that Greek funds achieve, on average, lower returns during the week before Easter, August 15th and Christmas, while returns are higher in the week after these holidays. ${ }^{1}$ In addition, we demonstrate that fund returns are more volatile during the week after the holidays.

The rest of the paper is organized as follows: Section 2 describes the main findings of the literature concerning seasonality in the U.S. or other international markets. The description of methodology applied to searching for seasonal patterns in return and risk of Greek equity funds follows in section 3. Section 4 presents the data of funds employed by the study and section 5 analyzes the empirical results. The paper concludes by summarizing the major inferences and providing suggestions for future expansion of the research regarding seasonality in Greek mutual funds' performance in section 6 .

1. August 15th is an important religious holiday for the Greek Orthodox Church. 


\section{Literature Review}

The literature has revealed various types of seasonal anomalies. At first, various studies such these of Rozeff and Kinney (1976), Roll (1983), Reinganum (1983), Keim (1983), Haugen and Lakonishok (1988), Ritter (1988), Lakonishok et al. (1991), D’Mello et al. (2003), Yakob et al. (2005), Starks et al. (2006), Haug and Hirschey (2006) and Bodla and Kiran (2006) indicate that stocks achieve abnormal equallyweighted returns during January. This pattern is called the January or the turn-of-theyear effect.

The literature usually relates the January effect to small-cap stocks, offering several explanations for its persistence in the U.S. market. Lakonishok et al. (1991) and, partially, Haug and Hirschey (2006) attribute the January effect to "window dressing" behavior, which assumes that professional investors redeem the low performing stocks and purchase high performing stocks at the end of the year in order to amend the performance of their portfolios. In addition, Aggarwal et al. (1990) report a strong January effect on returns of small-cap stocks listed on the Tokyo Stock Exchange.

D’Mello et al. (2003), Starks et al. (2006), Haug and Hirschey (2006) attribute the January effect to the tax-loss-selling hypothesis, which implies that investors sell the stocks that experienced large capital losses before the end of the year and postpone the sale of stocks with capital gains until after the first days of the New Year. The authors suggest that tax-loss selling behavior is mainly related to individual investors. Ritter (1988) also assumes that the January effect stems from the activity of "small" investors.

Apart from the January effect, some other monthly effects have been revealed by the literature. Chen and Singal (2003) point out the existence of a December momentum in return of winning stocks. According to the December effect hypothesis, investors postpone the selling of winners from December to January and possibly pressure the winners to gain increased returns during the last five days of December. The authors argue that the December effect is relatively easy to arbitrage and attribute its persistence to limited knowledge of its existence.

Furthermore, Bhabra et al. (1999) document the existence of a November effect on stock returns since the implementation of the Tax Reform Act of 1986, which shifted the tax-year end for mutual funds from December to October. The shift of tax-year end probably results in selling pressure within October of stocks that experienced capital losses during the year. Investors offset in this way the taxable gains at the beginning of the new tax year. Gibson et al. (2000) also report a strong November effect on stock returns since the 1986 Tax Reform Act, which leads to the sale of losers before the end of October. In addition, Milonas and Rompotis (2008) reveal the existence of a strong November effect on ETFs' return, risk and tracking error.

Some other monthly patterns on stock returns are documented in the literature. Ariel (1987) reports a half-month effect on returns of U.S. stock indices. This effect 
indicates that stocks display, on average, positive returns at the beginning and during the first half of each month and zero returns during the rest of the month. Boudreaux (1995) also reports the existence of a half-month effect on returns in various international stock markets such as those of Denmark, France and Germany. In addition, Ariel (1987) and Lakonishok and Smidt (1988) identify a turn-of-the-month effect on U.S. equity returns, which suggests that equity returns are unusually high during the interval which begins on the last trading day of each month and ends three days later.

Various studies reveal the impact of holidays on stock returns. Roll (1983) finds that small-cap stocks gain high returns on the last trading day before the first day of the New Year. Moreover, Lakonishok and Smidt (1984) report an increase in returns on the day before Christmas and argue that this increase concerns all stocks regardless the level of capitalization. Cadsby and Ratner (1992) reveal that the returns of stocks in Canada, Japan, Hong Kong, and Australia are high before the local holidays while Kim and Park (1994) reveal that the holiday effect applies to U.S., U.K. and Japanese stock markets even though each country has different holidays and characteristics. In addition, the authors show that the holiday effects in U.K. and Japan are independent of the holiday effects in U.S. stock markets.

Finally, a day-of-the-week effect is found by the literature. French (1980) finds that stock returns are high on Mondays. In contrast, Smirlock and Starks (1986) and Berument and Kiymaz (2001) find that Monday's average returns are negative. Furthermore, Gibbons and Hess (1981), Keim and Stambaugh (1984) and Agathee (2008) reveal that the average returns of stocks on Friday are abnormally high. A week-end effect on stock returns in U.K., Japan, Canada and Australia is revealed by Jaffe and Westerfield (1985). The authors find that the lowest returns for Japanese and Australian stock markets occur on Tuesday. There are, however, studies, such as these of Steeley (2001), Kohers et al. (2004), Hui (2005) and Chukwuogor (2008), that show that the day-of-the-week effect on stock returns has disappeared or at least weakened.

\section{Methodology}

\subsection{Day-of-the-Week Return and Risk}

We first examine the "day-of-the-week" returns of Greek equity funds. We estimate return using the net asset values at the end of each trading day via the following equation (1):

$$
\mathrm{R}_{\mathrm{i}}=\frac{N A V_{t}-N A V_{t-1}}{N A V_{t-1}} * 100
$$

where, $R_{i}$ refers to return on day $t$, and $\mathrm{NAV}_{\mathrm{t}}$ is the net asset value of fund I on day t. Afterwards, we isolate the Monday, Tuesday, Wednesday, Thursday and Friday 
returns and compute the average term for each single day of the week. Moreover, we estimate the returns' volatility for each day of the week. Volatility represents the risk of funds and is calculated as the standard deviation of the day-of-the-week returns.

After the calculation of day-of-the-week return and risk we search for seasonal patterns on the day-of-the-week returns in two ways. We first analyze the returns of each day and compare them to each other on an annual basis. We then apply dummy variable regression analysis so as to evaluate the differences in returns among the daily returns. More specifically, we apply the following regression (2):

$$
\text { Dret }=\alpha_{1}+\sum_{t=2}^{5} \alpha_{\mathrm{i}} \mathrm{D}_{\mathrm{i}}+\varepsilon_{\mathrm{pt}}
$$

where, Dret is the day-of-the-week return and the dependent variable of the model utilized in pool basis posturing vertically all the daily returns. The independent variables are four dummy variables for all days except Monday that take the value of 1 if the return is calculated on the specific day and the value of zero otherwise.

The model's intercept reflects the average return on Monday and comprises the comparative basis for the other dummies. The $\alpha_{i}$ coefficients count for the difference in returns between Monday and other days. If a positive Monday effect applies to Greek funds returns (French (1980)), we expect the estimations of alphas to be negative and significant. On the contrary, if a negative Monday effect applies to fund returns (Smirlock and Starks (1986)), we expect the coefficients of dummies to be positive. Furthermore, if returns are high on Fridays (Gibbons and Hess (1981) and Keim and Stambaugh (1984)), we expect the coefficient of Friday to be significant and higher than the coefficients of other days. Finally, the term $\varepsilon_{\mathrm{pt}}$ stands for the random error and it is expected to have zero mean. The model is estimated individually for all the years of the period.

\section{2 “Monthly" Return and Risk}

We isolate the net asset values of each fund among the calendar months and then we calculate the average daily returns of funds for each individual month. The average daily return in each month is characterized as the "monthly" return. We also estimate the "monthly" risk of funds, as the standard deviation of fund returns in each month.

We then search for seasonal patterns on "monthly" returns in two ways. We first analyze the returns of each month and compare them to each other on an annual basis and then we evaluate the significance of monthly returns via the following model (3):

$$
\text { Mret }=\alpha_{1}+\sum_{t=2}^{12} \alpha_{i} D_{i}+\varepsilon_{p t}
$$


where, Mret refers to "monthly" return and is the dependent variable of the model utilized in pool basis. The independent variables are eleven dummy variables for all months except January, which take the value of 1 if the return is calculated in the specific month and the value of zero otherwise.

The intercept of the model reflects the average return in January and comprises the comparative basis for the other calendar dummies. We choose January returns as the reference basis because the literature documents the existence of a strong January effect on stock returns. The $\alpha_{i}$ coefficients count for the difference in returns between January and other months. If the January effect applies to Greek funds, the $\alpha_{i}$ coefficients will be negative and statistically significant. The term $\varepsilon_{\mathrm{pt}}$ expresses the random error and it is expected to have zero mean. The model is estimated for each single year of the period.

\section{3 "Half-Monthly" Return and Risk}

To search for half-monthly effects on returns of Greek funds we first divide each month in two segments. The first segment includes the returns on days 1 to 15 and the second one includes the returns on days 16 to 30. If the day on the edge is Saturday or Sunday, the segments start or end from the prior or on the next trading day respectively. We then calculate the average daily or "half-monthly" return of each segment. We also calculate the "half-monthly" risk of funds.

After the calculations, we compare returns in the first and second half of the months and apply t-tests on the return difference between the first and the second half of the months. T-tests are applied to the cross sectional returns of all the funds of the sample. So, the number of observations in the column of cross sectional returns is equal to the number of available funds in each year of the study period. Based on the findings of Ariel (1987) and Boudreaux (1995), we expect funds to have positive returns during the first half of the months. In addition, we expect these returns to be higher than these in the second half of the months.

\section{4 "Holiday" Return and Risk}

The last research issue concerns the effects holidays have on performance of Greek equity funds. We examine holidays' effects considering three major holidays in Greece: Easter, $15^{\text {th }}$ of August and Christmas. We first isolate the daily returns of funds in the week before and after holidays respectively and calculate the average return of funds in each week. We also estimate "holidays" risk, which refers to the volatility of fund returns during the weeks before and after holidays.

We note that the duration of the week before and after holidays exceeds the five working days. More specifically, the first week starts on the second Monday before Easter and ends on the Thursday before Easter covering, an interval of nine trading days. The week after Easter covers the period which starts from the first Tuesday after 
Easter and ends on the second Friday after Easter. Moreover, when the $15^{\text {th }}$ of August and Christmas coincide with trading days, we expand the weekly interval up to the previous or the next Monday and Friday respectively. We assess weekly intervals this way so as to have a sufficient number of days to calculate average returns and search for seasonal patterns.

We evaluate the existence of any holiday effects on fund returns by comparing the returns in the weeks before and after holidays and applying t-tests to evaluate the significance of return differences. T-tests are applied considering the cross sectional returns of all the funds of the sample.

If the findings of Lakonishok and Smidt (1984) about the increased returns before Christmas and the findings of Cadsby and Ratner (1992) about the high stock returns before the local holidays in Canada, Japan, Hong Kong, and Australia apply to the Greek stock market, returns of funds will be higher in the week before holidays than in the week after holidays.

\section{Data}

We investigate seasonality using a sample of Greek equity funds during the period 2002-2005. Fund returns are calculated with daily net asset values gathered by the website of the Greek Institutional Investors Association. The number of funds is not constant among the successive years of the study. This is due to three major reasons. The first one is that some funds, which persistently present negative returns, disappeared or merged with other funds during the study period. Furthermore, some new funds were launched after the beginning of the study period. The last factor is due to the decision of the Hellenic Capital Market Commission on the abolition of the international funds class. ${ }^{2}$ This directive was effective from January $1^{\text {st }}, 2005$ and imposed the merger of international funds with other domestic or foreign funds. As a result, the number of funds was equal to 116 in 2002 and reduced to 102 in 2005.

We choose to include the ceased or the newly issued funds in our sample in order to deal with the survivorship bias problem. The survivorship bias problem reflects the upward impact on the reported average returns which derives from the absence of the non-existing funds. Return overvaluation occurs when the estimation of average returns does not take into account the performance of the ceased funds. We try to avoid overestimating returns by considering the returns of funds that do not currently exist. The basic requirement for the participation of a ceased fund in the sample is to complete net asset values for at least one entire year.

2. See Hellenic Capital Market Commission, Circular No.1/317, 11 November 2004. 


\section{Empirical Results}

\subsection{Day-of-the-Week Return and Risk}

Table 1 presents the average day-of-the-week returns and risks of Greek funds during the period 2002-2005. Results for 2002 indicate that the average returns of funds are negative in each single day of the week. This finding was to be expected as both Greek and international stocks experienced great losses during this year. Furthermore, results show that the average returns on Monday and Tuesday are equal to each other being simultaneously the lowest returns among all daily returns. More specifically, returns on Monday and Tuesday are equal to -0.23 . The least negative return in 2002 occurs on Thursday and is equal to -0.02 . Return on Friday stands close to Thursday's return being equal to -0.03 . Considering risk figures in 2002, we see that returns are more volatile on Mondays and less risky on Fridays.

The lowest average return in 2003 occurs on Tuesday and is equal to -0.01 while Monday's return is inferior to Tuesday's return only by 1 b.p. The highest average daily day-of-the-week return for the year occurs on Wednesday and is equal to 17 b.p. while Friday's return is the second highest for the year and equal to 16 b.p. On the question of risk, returns on Monday and Thursday are the most and least risky respectively.

The results for 2004 do not differ significantly from the previous years'. More specifically, funds deliver the worst return on Monday while they achieve their best performance on Friday. Furthermore, returns on Monday and Friday present essentially the same level of volatility. In particular, Monday and Friday risks are equal to 0.95 and 0.96 correspondingly.

Finally, Table 1 shows that the lowest average day-of-the-week return in 2005 relates to Wednesday. This return is negative and equal to -0.05 . The highest return for the year concerns Friday and is equal to 0.21 . With respect to risk, Monday is the most volatile trading day, while Friday bears the least risk for investors. The standard deviation of returns for these days is 0.77 and 0.62 respectively.

Considering the mean terms for the entire period, Table 1 indicates the existence of an average negative Monday effect on funds' performance. More specifically, the mean Monday return for the period is negative and equal to -0.07 . The mean results of the period are basically in line with the results of individual years, since Monday return is negative and almost the lowest in three of the four years of the study. The negative mean returns of Greek funds on Monday confirm our expectations and are in agreement with the findings of Smirlock and Starks (1986) and Berument and Kiymaz (2001). In addition, period's mean risk on Monday is the highest among all dayof-the-week risks indicating a positive Monday effect on fund's risk and an indirect relationship between performance and volatility on this day. 
Going further, period's mean terms reveal a strong positive Friday effect on return of Greek funds. This finding is consistent to those of Alexakis and Xanthakis (1995) and Coutts et al. (2000) for the Greek stock market and Gibbons and Hess (1981), Keim and Stambaugh (1984) and Agathee (2008) for international markets.

Table 2 presents the results of model (2), which evaluates the significance of the return differences between Monday and other days of the week. Considering results in 2002, the constant's coefficient is negative and significant at the $1 \%$ level while the estimations for Wednesday, Thursday and Friday dummy variables are positive and significant at the $1 \%$ level showing that return in these days is superior to Monday's returns. The coefficient for Tuesday is zero and indicates that return on Tuesday closely follows the return on Monday. Friday's coefficient is approximately the highest among all the coefficients revealing a positive Friday effect on fund performance.

The estimations for 2003 resemble these of 2002 and confirm the negative Monday effect on fund performance. More specifically, the constant is negative but insignificant, while the coefficients of Wednesday, Thursday and Friday are positive and significant at the $1 \%$ level. In addition, the estimate for Tuesday does not differ statistically from the coefficient for Monday. At the same time, the estimate for Friday (along with that for Wednesday) is the more positive among all estimations confirming the existence of a positive Friday effect on fund returns.

The results for 2004 are similar to these of previous years. The constant's estimate is negative and significant, while the coefficients of all the other days are positive and significant at the $1 \%$ level. These estimations confirm the negative Monday effect on funds' performance. Besides, the coefficient for Friday is the highest for the year indicating a clear Friday effect on returns.

Finally, the results for 2005 also confirm the existence of a positive Friday effect on performance as the coefficient of the Friday dummy variable is the highest for the year. Furthermore, results indicate that Monday's return is superior only to return on Wednesday.

\section{2 “Monthly” Return and Risk}

In this section we analyze the "monthly" returns of Greek equity funds during the period 2002-2005. Table 3 presents the average cross-sectional monthly returns and risks on an annual basis. The results for 2002 indicate that funds achieve the highest and lowest average returns in November and September respectively. The corresponding returns are equal to 0.24 and -0.56 . Furthermore, results show that the return in January is the third maximum monthly return for the year. In addition, the lowest volatility in fund returns occurs in March and the maximum risk in July. The results for 2002 indicate that the January effect does not apply to Greek equity funds in this year. 
Considering the results for 2003, the greater average monthly return concerns April, while the lowest return relates to September. The respective return figures are equal to 0.45 and -0.33 . The return in January is negative indicating the absence of a January impact on funds' returns in 2003. Moreover, the maximum and minimum risks relate to March and December respectively.

Results for 2004 reveal a strong January effect on returns. More specifically, the highest return for the year occurs in January and equals 27 b.p. On the other hand, the lowest monthly return for the year concerns May and is equal to - 0.12 . Furthermore, the highest and lowest risks for the year are connected with January and September. With respect to the results for 2005, the highest monthly return for the year relates to July and equals 26 b.p. On the contrary, the lowest return concerns March and is equal to -28 basis points. January's return is lower than that in July by 7 b.p. indicating the non-existence of the January effect on fund returns in 2005. Going further, the maximum risk concerns March and the lowest risk is connected both with May and September. The combination of the lowest return and highest risk in March indicates an occasional indirect interaction between return and risk in 2005.

The mean returns of the period confirm the absence of a persistent January effect on Greek funds' return. Overall, both the annual and the mean results for the period show that there is not any consistent monthly effect on fund returns and therefore we reject the hypothesis of monthly seasonal anomalies on fund returns.

Table 4 reports the estimations of model (3), which evaluates the statistical significance of return differences between January and other months. Results for 2002 indicate that the return in January is higher than almost all the other monthly returns. The coefficient of January is 0.05 being significant at the $1 \%$ level. The majority of the other coefficients are negative and significant at the 5\% level or better excepting those of October and November. October's estimate is positive but insignificant while November's coefficient equals 0.19 being significant at the $1 \%$ level of acceptance. Results show that the January effect applies only weakly to fund returns in 2002. The results for 2003 confirm the aforementioned non-existence of the January effect on returns. The results also confirm the statistical significance of the observed highest and lowest returns in April and September respectively. Furthermore, the results for 2004 verify the existence of a January effect on funds' performance for this year. Finally, the estimations for 2005 indicate that the maximum and minimum returns in July and March respectively are statistically significant. Overall, regression results demonstrate that the January effect is a dominant phenomenon in the Greek mutual funds market.

\section{3 "Half-Monthly" Return and Risk}

The "half-monthly" returns and risks of Greek funds are presented on a monthly basis in Panels A and B of Table 5 respectively. The results for 2002 indicate that returns 
are higher in the first half than those in the second half in six months. Moreover, the average first half-monthly return for the year is slightly higher than that of the second half-monthly return. In particular, the first half-monthly return of the year is equal to -0.12 and the respective second half-monthly return is equal to -0.14 . Thus, we infer that there is a marginal seasonal effect on fund returns during the first half of the months in 2002. Considering returns' volatility in 2002, results show that the risk of the first half-months is greater than that of the second half-months in six months. However, these months do not coincide with the months in which the return of first half-month exceeds the return of the second-half. The year's mean half-monthly risk is higher than the second half-monthly risk by 4 b.p.

Results for 2003 demonstrate a stronger seasonal effect on first half-monthly returns in comparison to the estimates for 2002. More specifically, the first half-monthly returns are higher than the second half-monthly ones in 8 months while the mean first half-monthly return of the year is equal to 18 b.p. The mean second half-monthly return is equal to -3 b.p. The first half-monthly risk is greater than the second halfmonthly risk in five months. Furthermore, the mean risk of all the first-half months exceeds the mean risk of the second-half months by 7 b.p. Combining the mean return with the mean risk in the first and second half-months of the year we confirm the positive correlation between performance and risk.

The results of half-monthly performance in 2004 are similar to those of the previous years. The first half-monthly return is superior to the second half-monthly return in 7 months while the year's mean return of all the first half-months is slightly higher than the respective mean of the second half-months only by 1 b.p. The risk's figures for 2004 contrast with those of the previous years. The risk in the first half is greater than the risk of the second half only in three months. In addition, the mean first halfmonthly risk for the year is inferior to the second half-monthly risk by 10 b.p.

Considering 2005, results show that the first half-monthly return outperforms the second half-monthly return in 8 months. In addition, the year's mean first halfmonthly return equals 13 b.p. while the year's second half-monthly return is equal to 6 b.p. These findings corroborate the evidence of a positive half-month effect on fund returns. Regarding funds' risk in 2005, Table 5 shows that the risk in first-half months is inferior to risk of second-half months in all the months of the year. The same relation applies to the respective mean risk figures for the whole year.

The last column of Panels A and B in Table 5 reports the period's mean first and second half-monthly return and risk of each month. The return of the first half-months is superior to the return of the second half-months in 8 months, while the period's mean first half-monthly return is equal to 0.06 and exceeds the period's mean second half-monthly return by 8 b.p. These results indicate a positive seasonal pattern on fund's performance during the first half of each month and agree with the findings of Ariel (1987) and Boudreaux (1995). Furthermore, the risk in the first half-months is 
greater that the risk in the second half-months in 5 months, while the period's mean first half-monthly risk is lower than the period's mean second half-monthly risk by 2 b.p.

Table 6 presents the average return differences between the first and the second half of each month. The difference in returns is calculated by subtracting the return of the second half from the return of the first half. Table 6 also presents the values of t-tests applied on the return differences. In 2002, results show that the differences between the returns of the first and second half-months are significant at the 5\% level or better in 10 months. In particular, the differences between the first and second halfmonths are statistically insignificant only in November and December. Furthermore, the difference between the mean first half-monthly and second half-monthly return of the year is equal to 0.03 , being significant at the $1 \%$ level, indicating that the first half-monthly returns are superior to the second half-monthly ones.

The results for 2003 are similar to those for 2002. The first and the second halfmonthly returns are statistically equal only in August, while the average difference for the entire year is equal to 0.21 , being significant at the $1 \%$ level, implying a strong seasonal effect on funds' performance.

The estimations for 2004 slightly differ from the results for the previous years. Specifically, return differences between the first and second half-months are significant in 8 months while the difference in year's mean first and second half-monthly returns is equal to 0.02 but insignificant at any acceptable level.

Finally, the results for 2005 indicate a strong seasonal effect on fund returns in the first half of the months. The first and second half-monthly returns are statistically different in 10 months while the difference between the year's mean first and second half-monthly return is equal to 7 b.p., being significant at the $1 \%$ level.

\section{4 "Holiday" Return and Risk}

The last research issue concerns the effects caused by holidays on fund returns. Three holidays are considered: Easter, $15^{\text {th }}$ of August and Christmas. Table 7 presents the return and risk of Greek funds in the week before and after holidays. The results for 2002 indicate that funds produce higher gains in the week after Easter and August $15^{\text {th }}$ while returns before Christmas are less negative than those after Christmas. The findings concerning Christmas are in agreement with these of Lakonishok and Smidt (1984). With respect to average terms, the results show that return in the week before holidays is negative and equal to -0.11 , while the average return in the week after the holidays is positive and equal to 15 b.p. This finding reflects a seasonal pattern in returns during the week after holidays and contrasts with the results of Cadsby and Ratner (1992), who find that stock returns in Canada, Japan, Hong Kong and Australia are high before the local holidays. Risk presents no constant behavior before and after holidays during 2002. For instance, risk is lower in the week before Easter than 
that in the week after Easter while it is higher in the week before August $15^{\text {th }}$ than the risk in the week after this holiday.

The results for 2003 reveal that the average return before Easter is higher than the return after Easter while returns before August $15^{\text {th }}$ and Christmas are inferior to the respective returns after these holidays. In addition, the mean return in the week after holidays is higher than the mean return in the week before holidays (48 b.p. and 12 b.p. respectively). This finding confirms the existence of seasonal patterns on fund returns after holidays. Considering returns' volatility in 2003, the results show that risk is greater in the week after Easter and Christmas than the risk in the week before these holidays. The opposite relationship applies to August $15^{\text {th }}$.

The results for 2004 resemble the results for 2003. The return before Easter is superior to that after Easter while returns before August $15^{\text {th }}$ and Christmas are lower than returns after these holidays. Moreover, the mean return before and after holidays is equal to 0.06 and 0.20 respectively, verifying the existence of seasonal anomalies in fund returns after holidays. Going further, the mean risk of all holidays is greater in the week after holidays than that in the week before holidays while the behavior of risk before and after the individual holidays varies.

Finally, the results for 2005 reveal that return is higher in the week after Easter and Christmas than in the week before these days. The opposite pattern applies to returns around August $15^{\text {th }}$. Similarly to previous years' results, volatility figures indicate that risk does not behave in a constant way before and after holidays. For instance, risk is higher in the week before Easter than that in the week after Easter while the opposite relationship applies to risk measures before and after Christmas.

The period's mean returns indicate the existence of a strong seasonal effect on fund return in the week after holidays. More specifically, the mean returns in the weeks after holidays are superior to these in the weeks before these days. In addition, period's mean risk is greater in the week after Easter and Christmas than that in the week before these days while the opposite pattern applies to mean return volatilities around Easter.

Table 8 reports the values of t-statistics, which assess the statistical significance of return differences in the week before and after each holiday. The difference in returns is calculated by subtracting the cross-sectional average returns of funds in the week before holidays from the respective average returns in the week after holidays.

T-statistics for 2002 indicate that the return differences around Easter, August $15^{\text {th }}$ and Christmas are statistically significant at the $5 \%$ level or better while the difference in mean holiday returns is significant at the $1 \%$ level. Differences are also significant in 2003. Finally, t-statistics for 2004 and 2005 indicate that returns are significantly different in Easter and August 15 but not in Christmas. The same pattern applies to the mean holiday returns for these years. 


\section{Conclusions}

In this paper we search for seasonal anomalies in performance of Greek equity funds during the period 2002-2005. Four types of seasonality are considered: the day-ofthe-week effect, the monthly effect, the half-monthly effect and the holiday effect. We provide strong evidence for seasonal patterns in fund returns and expand the relevant research into the Greek stock market, as the previous studies on seasonal anomalies in the Greek market have mainly focused on market indices or individual stocks.

At first, we demonstrate that a strong day-of-the-week effect applies to the return of Greek funds. More specifically, we find that returns on Monday are, on average, negative while they are abnormally high on Fridays. These results are consistent with the previous findings of the literature relating both to the Greek market (e.g. Alexakis and Xanthakis (1995), Mills et al. (2000)) and international markets (e.g. Smirlock and Starks (1986), Gibbons and Hess (1981) and Keim and Stambaugh (1984)). In addition, we reveal that Monday's returns are more volatile relative to returns on other days indicating that investors are exposed to great volatility on this day without being compensated by higher returns.

Considering the monthly effects, we show that the (well-documented in the finance literature) January effect applies very weakly to returns of Greek funds. We find evidence for a clear and strong January effect only in one year of the study period. In addition, we do not find any other persistent monthly effect on fund returns. However, we reveal that fund returns are strongly affected by a half-monthly effect. In particular, we find that, on average, returns are higher in the first half-month of the months than returns in the second half of the months. These results are in agreement with findings provided by Ariel (1987) and Boudreaux (1995). Moreover, we indicate that return's volatility does not present a constant behavior through time. This means that risk in the first-half of the months is either higher or lower than the risk in the second half-months.

Finally, we provide evidence for positive seasonal effects on fund returns after Easter, August $15^{\text {th }}$ and Christmas, which means that, on average, funds achieve better returns in the week after the holidays. These findings contrast with Lakonishok and Smidt (1984) and Cadsby and Ratner (1992). In addition, we find that the average risk in the week after holidays is higher than that in the week before holidays.

Overall, the results of this paper demonstrate that the seasonality in stock returns revealed by the literature applies to Greek equity funds too. Therefore, investors could possibly apply profitable and risk efficient short-term strategies by investing in Greek equity funds. These strategies could possibly beat simple buy-and-hold strategies and result in a much improved risk-adjusted performance.

The research into the seasonal behavior of Greek mutual funds' performance could be expanded in several ways. At first, we could use data for a broader time horizon so as to obtain more sound and robust evidence on the performance of equity 
funds. In addition, we could simulate momentum and buy-and-hold trading strategies and investigate whether the first outperforms the second, or vice versa. We could also examine whether the other investing classes, such as the fixed income or balanced funds, are influenced by any seasonal anomalies. Finally, we could examine whether seasonality-based strategies investing in equity shares outperform the seasonalitybased strategies that invest in the less risky bond of fixed income securities. 


\section{Table 1}

\section{"Day-of-the-Week" Return and Risk}

This table reports the day-of-the-week return and standard deviation of Greek equity funds during the period 2002-2005. Presented are the average percentage daily return of the sample and the average standard deviation of returns in Panels A and B respectively. $\mathrm{N}$ expresses the number of funds available each year. The number of Mondays, Tuesdays, etc is also presented.

\begin{tabular}{|c|c|c|c|c|c|}
\hline \multicolumn{6}{|c|}{ Panel A: Day-of-the-Week Return } \\
\hline & 2002 & 2003 & 2004 & 2005 & Period's Mean \\
\hline Monday & -0.23 & -0.02 & -0.14 & 0.10 & -0.07 \\
\hline Tuesday & -0.23 & -0.01 & 0.04 & 0.10 & -0.03 \\
\hline Wednesday & -0.15 & 0.17 & 0.11 & -0.05 & 0.02 \\
\hline Thursday & -0.02 & 0.08 & 0.01 & 0.10 & 0.04 \\
\hline Friday & -0.03 & 0.16 & 0.14 & 0.21 & 0.12 \\
\hline Weekly Mean & -0.13 & 0.08 & 0.03 & 0.09 & 0.02 \\
\hline $\mathrm{N}$ & 116 & 112 & 114 & 102 & 111 \\
\hline No of Mondays & 47 & 48 & 49 & 47 & 48 \\
\hline No of Tuesdays & 52 & 50 & 51 & 52 & 51 \\
\hline No of Wednesdays & 51 & 53 & 52 & 52 & 52 \\
\hline No of Thursdays & 50 & 50 & 51 & 51 & 51 \\
\hline No of Fridays & 51 & 49 & 51 & 49 & 50 \\
\hline \multicolumn{6}{|c|}{ Panel B: Day-of-the-Week Risk } \\
\hline & 2002 & 2003 & 2004 & 2005 & Period's Mean \\
\hline Monday & 1.25 & 1.36 & 0.95 & 0.77 & 1.08 \\
\hline Tuesday & 1.12 & 1.06 & 0.70 & 0.69 & 0.89 \\
\hline Wednesday & 1.10 & 1.01 & 0.73 & 0.74 & 0.90 \\
\hline Thursday & 1.14 & 0.96 & 0.81 & 0.75 & 0.92 \\
\hline Friday & 1.09 & 1.19 & 0.96 & 0.62 & 0.97 \\
\hline Weekly Mean & 1.14 & 1.12 & 0.83 & 0.71 & 0.95 \\
\hline $\mathrm{N}$ & 116 & 112 & 114 & 102 & 111 \\
\hline No of Mondays & 47 & 48 & 49 & 47 & 48 \\
\hline No of Tuesdays & 52 & 50 & 51 & 52 & 51 \\
\hline No of Wednesdays & 51 & 53 & 52 & 52 & 52 \\
\hline No of Thursdays & 50 & 50 & 51 & 51 & 51 \\
\hline No of Fridays & 51 & 49 & 51 & 49 & 50 \\
\hline
\end{tabular}


Table 2

\section{Regression Results in "Day-of-the-Week" Return Seasonality}

The table reports the results of the pool regression model which evaluates the seasonality in the dayof-the-week return of Greek equity funds. The model is expressed by the following equation:

$$
\text { DRet }=\alpha_{1}+\sum_{t=2}^{5} \alpha_{i} D_{i}+\varepsilon_{p t}
$$

The dependent variable of the model is the day-of-the-week return of funds. Model's intercept reflects the average return on Monday. The model's control variables are four dummy variables for Tuesday, Wednesday, Thursday and Friday. Alphas reflect the difference in returns between Monday and other days. The random error term $\varepsilon_{\mathrm{pt}}$ is expected to have zero mean. T-stat values count for the statistical significance of the estimations. Obs. reflects the number of pool observations in each year. R-square evaluates the explanatory power of the model and F-statistic measures the joint significance of the coefficients of dummy variables.

\begin{tabular}{|c|c|c|c|c|c|c|c|c|}
\hline \multirow[b]{2}{*}{ Day } & \multicolumn{2}{|c|}{2002} & \multicolumn{2}{|c|}{2003} & \multicolumn{2}{|c|}{2004} & \multicolumn{2}{|c|}{2005} \\
\hline & Coefs & T-stat & Coefs & T-stat & Coefs & T-stat & Coefs & T-stat \\
\hline Monday & $-0.23^{*}$ & -22.22 & -0.02 & -1.44 & $-0.14^{*}$ & -9.89 & $0.10^{*}$ & 9.50 \\
\hline Tuesday & 0.00 & 0.17 & 0.01 & 0.50 & $0.18^{*}$ & 8.92 & 0.01 & 0.53 \\
\hline Wednesday & $0.08^{*}$ & 5.52 & $0.19^{*}$ & 6.84 & $0.25^{\star}$ & 12.56 & $-0.14^{*}$ & -13.14 \\
\hline Thursday & $0.21^{*}$ & 14.70 & $0.10^{*}$ & 3.71 & $0.16^{*}$ & 7.72 & 0.01 & 0.46 \\
\hline Friday & $0.20^{*}$ & 13.75 & $0.19^{*}$ & 6.62 & $0.28^{*}$ & 13.88 & $0.11^{*}$ & 8.00 \\
\hline Obs. & \multicolumn{2}{|c|}{580} & \multicolumn{2}{|c|}{560} & \multicolumn{2}{|c|}{570} & \multicolumn{2}{|c|}{510} \\
\hline $\mathrm{R}^{2}$ & \multicolumn{2}{|c|}{0.38} & \multicolumn{2}{|c|}{0.13} & \multicolumn{2}{|c|}{0.30} & \multicolumn{2}{|c|}{0.52} \\
\hline F-Stat & \multicolumn{2}{|c|}{$58.59^{*}$} & \multicolumn{2}{|c|}{$21.12^{*}$} & \multicolumn{2}{|c|}{$59.21^{*}$} & \multicolumn{2}{|c|}{$136.09^{*}$} \\
\hline
\end{tabular}

\footnotetext{
* Significant at the $1 \%$ level
} 


\section{Table 3}

\section{"Monthly" Return and Risk}

This table reports the monthly return and standard deviation of Greek equity funds during the period 2002-2005. Monthly return reflects the average daily return of funds in each calendar month. Presented are the average percentage daily return in each month and the average standard deviation of returns in Panels A and B respectively. $\mathrm{N}$ expresses the number of funds available each year. The number of trading days in January (January Obs.) and the average number of trading days in other months (Non Jan. Obs.) are also presented.

\begin{tabular}{|c|c|c|c|c|c|}
\hline \multicolumn{6}{|c|}{ Panel A: "Monthly" Return } \\
\hline & 2002 & 2003 & 2004 & 2005 & Period's Mean \\
\hline January & 0.05 & -0.20 & 0.27 & 0.19 & 0.08 \\
\hline February & -0.32 & -0.13 & -0.02 & 0.20 & -0.07 \\
\hline March & 0.00 & -0.23 & -0.11 & -0.28 & -0.16 \\
\hline April & -0.15 & 0.45 & 0.11 & -0.05 & 0.09 \\
\hline May & 0.01 & 0.06 & -0.12 & 0.21 & 0.04 \\
\hline June & -0.27 & 0.31 & -0.02 & 0.14 & 0.04 \\
\hline July & -0.23 & 0.39 & -0.08 & 0.26 & 0.09 \\
\hline August & -0.01 & 0.16 & -0.05 & -0.03 & 0.02 \\
\hline September & -0.56 & -0.33 & -0.01 & 0.17 & -0.18 \\
\hline October & 0.10 & 0.28 & 0.14 & -0.11 & 0.10 \\
\hline November & 0.24 & 0.03 & 0.14 & 0.16 & 0.14 \\
\hline December & -0.43 & 0.13 & 0.18 & 0.23 & 0.03 \\
\hline Monthly Mean & -0.13 & 0.08 & 0.03 & 0.09 & 0.02 \\
\hline $\mathrm{N}$ & 116 & 112 & 114 & 102 & 111 \\
\hline January Obs. & 22 & 21 & 20 & 20 & 21 \\
\hline Non Jan. Obs. & 21 & 21 & 21 & 21 & 21 \\
\hline \multicolumn{6}{|c|}{ Panel B: "Monthly" Risk } \\
\hline & 2002 & 2003 & 2004 & 2005 & Period's Mean \\
\hline January & 0.97 & 1.11 & 1.01 & 0.70 & 0.95 \\
\hline February & 0.88 & 0.83 & 0.79 & 0.67 & 0.79 \\
\hline March & 0.86 & 1.59 & 1.18 & 0.89 & 1.13 \\
\hline April & 0.89 & 0.93 & 0.83 & 0.83 & 0.87 \\
\hline May & 1.02 & 0.95 & 0.95 & 0.63 & 0.89 \\
\hline June & 1.07 & 1.10 & 0.58 & 0.67 & 0.86 \\
\hline July & 1.49 & 1.13 & 0.62 & 0.73 & 0.99 \\
\hline August & 1.08 & 0.98 & 0.69 & 0.65 & 0.85 \\
\hline September & 1.33 & 1.11 & 0.53 & 0.63 & 0.90 \\
\hline October & 1.44 & 1.35 & 0.73 & 0.81 & 1.08 \\
\hline November & 1.07 & 0.81 & 0.73 & 0.60 & 0.80 \\
\hline December & 0.90 & 0.61 & 0.86 & 0.78 & 0.79 \\
\hline Monthly Mean & 1.08 & 1.04 & 0.79 & 0.71 & 0.91 \\
\hline $\mathrm{N}$ & 116 & 112 & 114 & 102 & 111 \\
\hline January Obs. & 22 & 21 & 20 & 20 & 21 \\
\hline Non Jan. Obs. & 21 & 21 & 21 & 21 & 21 \\
\hline
\end{tabular}




\section{Table 4}

\section{Regression Results in "Monthly" Return Seasonality}

The table reports the results of the pool regression model which evaluates the seasonality in monthly return of Greek equity funds. The model is expressed by the following equation:

$$
\text { MRet }=\alpha_{1}+\sum_{t=2}^{12} \alpha_{\mathrm{i}} \mathrm{D}_{\mathrm{i}}+\varepsilon_{\mathrm{pt}}
$$

The dependent variable of the model is the "monthly" return of funds, which implies the average daily return of funds in each month. Model's intercept reflects the average return in January. The model's control variables are eleven dummy variables for the other months of the year. Alphas measure the difference in returns between January and other months. The random error term $\varepsilon_{\mathrm{pt}}$ is expected to have zero mean. The model is estimated individually for all the years of the studying period. T-stat values count for the statistical significance of the estimations. Obs. reflects the number of pool observations in each year. R-square evaluates the explanatory power of the model and F-statistic measures the joint significance of the coefficients of dummy variables.

\begin{tabular}{|c|c|c|c|c|c|c|c|c|}
\hline \multirow[b]{2}{*}{ Day } & \multicolumn{2}{|c|}{2002} & \multicolumn{2}{|c|}{2003} & \multicolumn{2}{|c|}{2004} & \multicolumn{2}{|c|}{2005} \\
\hline & Coefs & T-stat & Coefs & T-stat & Coefs & T-stat & Coefs & T-stat \\
\hline January & $0.05^{\star}$ & 3.69 & $-0.20^{*}$ & -10.50 & $0.27^{*}$ & 12.55 & $0.19^{*}$ & 15.23 \\
\hline February & $-0.37^{*}$ & -16.47 & $0.07^{*}$ & 2.59 & $-0.29^{*}$ & -9.61 & 0.01 & 0.49 \\
\hline March & $-0.05^{* *}$ & -2.40 & -0.03 & -1.01 & $-0.38^{*}$ & -12.68 & $-0.47^{*}$ & -20.29 \\
\hline April & $-0.20^{\star}$ & -9.40 & $0.65^{\star}$ & 23.86 & $-0.16^{*}$ & -5.29 & $-0.24^{*}$ & -14.78 \\
\hline May & -0.04 & -1.65 & $0.26^{*}$ & 9.57 & $-0.38^{*}$ & -12.77 & 0.02 & 0.99 \\
\hline June & $-0.32^{*}$ & -10.72 & $0.51^{*}$ & 18.65 & $-0.29^{*}$ & -9.53 & $-0.05^{\star}$ & -3.90 \\
\hline July & $-0.28^{*}$ & -17.42 & $0.59^{*}$ & 21.62 & $-0.34^{*}$ & -11.47 & $0.06^{*}$ & 3.85 \\
\hline August & $-0.06^{\star}$ & -3.95 & $0.36^{*}$ & 13.38 & $-0.32^{*}$ & -10.66 & $-0.23^{*}$ & -15.59 \\
\hline September & $-0.61^{*}$ & -34.33 & $-0.13^{*}$ & -4.75 & $-0.28^{*}$ & -9.30 & -0.02 & -1.40 \\
\hline October & 0.05 & 1.61 & $0.48^{*}$ & 17.70 & $-0.13^{*}$ & -4.38 & $-0.31^{*}$ & -19.93 \\
\hline November & $0.19^{*}$ & 10.04 & $0.23^{*}$ & 8.46 & $-0.12^{*}$ & -4.12 & $-0.03^{* *}$ & -2.08 \\
\hline December & $-0.48^{*}$ & -23.39 & $0.33^{*}$ & 12.18 & $-0.08^{*}$ & -2.81 & 0.04 & 1.08 \\
\hline Obs. & \multicolumn{2}{|c|}{1392} & \multicolumn{2}{|c|}{1344} & \multicolumn{2}{|c|}{1368} & \multicolumn{2}{|c|}{1224} \\
\hline $\mathrm{R}^{2}$ & \multicolumn{2}{|c|}{0.64} & \multicolumn{2}{|c|}{0.59} & \multicolumn{2}{|c|}{0.22} & \multicolumn{2}{|c|}{0.50} \\
\hline F-Stat & \multicolumn{2}{|c|}{$220.96 *$} & \multicolumn{2}{|c|}{$176.94^{*}$} & \multicolumn{2}{|c|}{$35.61^{*}$} & \multicolumn{2}{|c|}{$110.97^{*}$} \\
\hline
\end{tabular}

* Significant at the $1 \%$ level

** Significant at the $5 \%$ level 


\section{Table 5}

\section{"Half-Monthly" Return and Risk}

This table reports the half-monthly return and standard deviation of Greek equity funds during the period 2002-2005. Half-monthly return reflects the average daily return of funds in the first and the second half of each month. Presented are the average percentage daily return in each halfmonth and the average standard deviation of returns in Panels A and B respectively. $\mathrm{N}$ expresses the number of funds available each year. The average number trading of $1^{\text {st }}$ and $2^{\text {nd }}$ half-month is also presented ( $1^{\text {st }}$ half-month obs. and $2^{\text {nd }}$ half-month obs. respectively).

\begin{tabular}{|c|c|c|c|c|c|c|}
\hline \multicolumn{7}{|c|}{ Panel A: "Half-Monthly" Return } \\
\hline & & 2002 & 2003 & 2004 & 2005 & Period's Mean \\
\hline \multirow{2}{*}{ January } & $1^{\text {st }}$ Half & -0.12 & 0.01 & 0.64 & 0.25 & 0.20 \\
\hline & $2^{\text {nd }}$ Half & 0.19 & -0.36 & -0.04 & 0.19 & -0.01 \\
\hline \multirow{2}{*}{ February } & $1^{\text {st }}$ Half & -0.24 & -0.09 & 0.00 & 0.24 & -0.02 \\
\hline & $2^{\text {nd }}$ Half & -0.41 & -0.17 & -0.04 & 0.16 & -0.12 \\
\hline \multirow{2}{*}{ March } & $1^{\text {st }}$ Half & 0.19 & -0.36 & -0.31 & -0.12 & -0.15 \\
\hline & $2^{\text {nd }}$ Half & -0.27 & -0.11 & 0.08 & -0.42 & -0.18 \\
\hline \multirow{2}{*}{ April } & $1^{\text {st }}$ Half & -0.34 & 0.65 & 0.25 & 0.07 & 0.16 \\
\hline & $2^{\text {nd }}$ Half & 0.04 & 0.20 & -0.01 & -0.20 & 0.01 \\
\hline \multirow{2}{*}{ May } & $1^{\text {st }}$ Half & 0.40 & 0.20 & -0.19 & 0.14 & 0.14 \\
\hline & $2^{\text {nd }}$ Half & -0.24 & -0.07 & -0.04 & 0.26 & -0.02 \\
\hline \multirow{2}{*}{ June } & $1^{\text {st }}$ Half & -0.38 & 0.67 & 0.01 & 0.29 & 0.15 \\
\hline & $2^{\text {nd }}$ Half & -0.15 & -0.06 & -0.05 & -0.02 & -0.07 \\
\hline \multirow{2}{*}{ July } & $1^{\text {st }}$ Half & -0.38 & 0.60 & -0.16 & 0.18 & 0.06 \\
\hline & $2^{\text {nd }}$ Half & -0.09 & 0.19 & 0.01 & 0.34 & 0.11 \\
\hline \multirow{2}{*}{ August } & $1^{\text {st }}$ Half & 0.01 & 0.14 & -0.35 & -0.02 & -0.06 \\
\hline & $2^{\text {nd }}$ Half & -0.03 & 0.18 & 0.17 & -0.05 & 0.07 \\
\hline \multirow{2}{*}{ September } & $1^{\text {st }}$ Half & -0.51 & -0.44 & 0.06 & 0.12 & -0.19 \\
\hline & $2^{\text {nd }}$ Half & -0.61 & -0.22 & -0.09 & 0.22 & -0.18 \\
\hline \multirow{2}{*}{ October } & $1^{\text {st }}$ Half & 0.19 & 0.56 & 0.14 & -0.19 & 0.18 \\
\hline & $2^{\text {nd }}$ Half & 0.01 & 0.00 & 0.13 & -0.03 & 0.03 \\
\hline \multirow{2}{*}{ November } & $1^{\text {st }}$ Half & 0.23 & 0.12 & 0.33 & 0.29 & 0.24 \\
\hline & $2^{\text {nd }}$ Half & 0.25 & -0.07 & -0.05 & 0.04 & 0.04 \\
\hline \multirow{2}{*}{ December } & $1^{\text {st }}$ Half & -0.45 & 0.11 & 0.13 & 0.25 & 0.01 \\
\hline & $2^{\text {nd }}$ Half & -0.40 & 0.15 & 0.23 & 0.21 & 0.05 \\
\hline \multirow{2}{*}{ Half Monthly Mean } & $1^{\text {st }}$ Half & -0.12 & 0.18 & 0.04 & 0.13 & 0.06 \\
\hline & $2^{\text {nd }}$ Half & -0.14 & -0.03 & 0.03 & 0.06 & -0.02 \\
\hline $\mathrm{N}$ & & 116 & 112 & 114 & 102 & 111 \\
\hline $1^{\text {st }}$ Half Obs. & & 10 & 10 & 10 & 11 & 10 \\
\hline $2^{\text {nd }}$ Half Obs. & & 11 & 10 & 11 & 11 & 11 \\
\hline
\end{tabular}


Table 5 (continued)

\begin{tabular}{|c|c|c|c|c|c|c|}
\hline \multicolumn{7}{|c|}{ Panel B: “Half-Monthly” Risk } \\
\hline & & 2002 & 2003 & 2004 & 2005 & Period's Mean \\
\hline \multirow{2}{*}{ January } & $1^{\text {st }}$ Half & 1.03 & 1.14 & 0.87 & 0.66 & 0.93 \\
\hline & $2^{\text {nd }}$ Half & 0.57 & 1.06 & 1.00 & 0.73 & 0.84 \\
\hline \multirow{2}{*}{ February } & $1^{\text {st }}$ Half & 0.97 & 0.77 & 0.74 & 0.67 & 0.79 \\
\hline & $2^{\text {nd }}$ Half & 0.98 & 0.89 & 0.83 & 0.67 & 0.84 \\
\hline \multirow{2}{*}{ March } & $1^{\text {st }}$ Half & 1.09 & 1.56 & 1.05 & 0.68 & 1.10 \\
\hline & $2^{\text {nd }}$ Half & 0.88 & 1.67 & 1.30 & 1.01 & 1.22 \\
\hline \multirow{2}{*}{ April } & $1^{\text {st }}$ Half & 1.14 & 1.00 & 0.90 & 0.79 & 0.96 \\
\hline & $2^{\text {nd }}$ Half & 1.18 & 0.79 & 0.76 & 0.87 & 0.90 \\
\hline \multirow{2}{*}{ May } & $1^{\text {st }}$ Half & 1.15 & 0.93 & 0.97 & 0.60 & 0.91 \\
\hline & $2^{\text {nd }}$ Half & 1.76 & 0.96 & 0.94 & 0.65 & 1.08 \\
\hline \multirow{2}{*}{ June } & $1^{\text {st }}$ Half & 1.19 & 1.09 & 0.55 & 0.61 & 0.86 \\
\hline & $2^{\text {nd }}$ Half & 0.98 & 0.98 & 0.61 & 0.70 & 0.82 \\
\hline \multirow{2}{*}{ July } & $1^{\text {st }}$ Half & 0.90 & 1.29 & 0.38 & 0.67 & 0.81 \\
\hline & $2^{\text {nd }}$ Half & 1.12 & 0.95 & 0.76 & 0.76 & 0.90 \\
\hline \multirow{2}{*}{ August } & $1^{\text {st }}$ Half & 0.59 & 0.89 & 0.66 & 0.59 & 0.68 \\
\hline & $2^{\text {nd }}$ Half & 0.72 & 1.07 & 0.62 & 0.68 & 0.77 \\
\hline \multirow{2}{*}{ September } & $1^{\text {st }}$ Half & 0.85 & 1.05 & 0.50 & 0.58 & 0.75 \\
\hline & $2^{\text {nd }}$ Half & 1.24 & 1.15 & 0.56 & 0.67 & 0.91 \\
\hline \multirow{2}{*}{ October } & $1^{\text {st }}$ Half & 1.76 & 1.59 & 0.66 & 0.72 & 1.18 \\
\hline & $2^{\text {nd }}$ Half & 1.01 & 0.84 & 0.83 & 0.89 & 0.89 \\
\hline \multirow{2}{*}{ November } & $1^{\text {st }}$ Half & 1.49 & 0.77 & 0.69 & 0.58 & 0.88 \\
\hline & $2^{\text {nd }}$ Half & 1.06 & 0.86 & 0.73 & 0.61 & 0.82 \\
\hline \multirow{2}{*}{ December } & $1^{\text {st }}$ Half & 0.94 & 0.58 & 0.62 & 0.55 & 0.67 \\
\hline & $2^{\text {nd }}$ Half & 0.81 & 0.64 & 0.91 & 0.88 & 0.81 \\
\hline \multirow{2}{*}{ Half Monthly Mean } & $1^{\text {st }}$ Half & 1.08 & 1.06 & 0.72 & 0.64 & 0.88 \\
\hline & $2^{\text {nd }}$ Half & 1.04 & 0.99 & 0.82 & 0.76 & 0.90 \\
\hline $\mathrm{N}$ & & 116 & 112 & 114 & 102 & 111 \\
\hline $1^{\text {st }}$ Half Obs. & & 10 & 10 & 10 & 11 & 10 \\
\hline $2^{\text {nd }}$ Half Obs. & & 11 & 10 & 11 & 11 & 11 \\
\hline
\end{tabular}




\section{Table 6}

\section{T-tests on the "Half-Monthly" Return Seasonality}

The table reports the average difference between the return of the first and second half-months of each month. The difference is calculated by subtracting the average return of the second half-month from that of the first half-month. The statistical significance of the difference is examined via t-test applied on the difference between the average returns. Obs. refers to the number of observations and coincides with the number of funds available each year.

\begin{tabular}{|c|c|c|c|c|}
\hline Coefficients & 2002 & 2003 & 2004 & 2005 \\
\hline January & $-0.31^{*}$ & $0.37^{\star}$ & $0.68^{*}$ & $0.07^{*}$ \\
\hline T-statistic & -13.10 & 7.03 & 17.90 & 3.89 \\
\hline February & $0.17^{*}$ & $0.08^{*}$ & 0.04 & $0.08^{*}$ \\
\hline T-statistic & 6.67 & 3.94 & 1.56 & 3.13 \\
\hline March & $0.46^{*}$ & $-0.26^{*}$ & $-0.40^{*}$ & $0.30^{*}$ \\
\hline T-statistic & 22.59 & -10.21 & -28.02 & 9.03 \\
\hline April & $-0.38^{*}$ & $0.46^{*}$ & $0.26^{*}$ & $0.28^{*}$ \\
\hline T-statistic & -12.92 & 20.25 & 9.49 & 9.75 \\
\hline May & $0.64^{*}$ & $0.28^{*}$ & $-0.15^{\star}$ & $-0.12^{*}$ \\
\hline T-statistic & 31.15 & 18.34 & -6.61 & -9.66 \\
\hline June & $-0.24^{*}$ & $0.72^{*}$ & $0.07^{*}$ & $0.31^{*}$ \\
\hline T-statistic & -7.53 & 19.17 & 4.54 & 21.22 \\
\hline July & $-0.29^{*}$ & $0.42^{*}$ & $-0.17^{*}$ & $-0.16^{*}$ \\
\hline T-statistic & -7.50 & 23.11 & -5.70 & -5.24 \\
\hline August & $0.04^{\star *}$ & -0.04 & $-0.52^{*}$ & 0.03 \\
\hline T-statistic & 2.00 & -1.34 & -16.17 & 1.26 \\
\hline September & $0.11^{*}$ & $-0.22^{*}$ & $0.15^{\star}$ & $-0.10^{*}$ \\
\hline T-statistic & 3.57 & -5.37 & 13.63 & -7.03 \\
\hline October & $0.18^{*}$ & $0.56^{*}$ & 0.00 & $-0.16^{*}$ \\
\hline T-statistic & 6.14 & 5.26 & 0.32 & -6.01 \\
\hline November & -0.02 & $0.19^{*}$ & $0.38^{*}$ & $0.25^{*}$ \\
\hline T-statistic & -1.13 & 14.71 & 31.59 & 16.62 \\
\hline December & -0.05 & $-0.04^{*}$ & -0.10 & 0.04 \\
\hline T-statistic & -1.61 & -3.14 & -0.82 & 0.54 \\
\hline Yearly Mean & $0.03^{*}$ & $0.21^{*}$ & 0.02 & $0.07^{*}$ \\
\hline T-statistic & 3.12 & 18.26 & 1.50 & 6.95 \\
\hline Obs. & 116 & 112 & 114 & 102 \\
\hline
\end{tabular}

* Significant at the $1 \%$ level

** Significant at the $5 \%$ level 


\section{Table 7}

\section{"Holiday" Return and Risk}

This table reports the return and standard deviation of Greek equity funds in the weeks before (t-1) and after ( $\mathrm{t}+1)$ Easter, August $15^{\text {th }}$ and Christmas during the period 2002-2005. Holidays return reflects the average daily return during the relevant weeks. Presented are the average percentage daily return in each week and the average standard deviation of returns in Panels A and B respectively. Obs. refers to the number of trading days in week $t-1$ and $t+1$ respectively. $N$ expresses the number of funds available each year.

\begin{tabular}{|c|c|c|c|c|c|c|}
\hline \multicolumn{7}{|c|}{ Panel A: "Holidays" Return } \\
\hline Holidays & Week & 2002 & 2003 & 2004 & 2005 & Period's Mean \\
\hline \multirow{2}{*}{ Easter } & Week $_{\mathrm{t}-1}$ & -0.17 & 0.25 & 0.46 & -0.20 & 0.09 \\
\hline & Week $_{t+1}$ & 0.55 & 0.15 & 0.13 & 0.14 & 0.24 \\
\hline \multirow{2}{*}{ Obs. } & Week $_{t-1}$ & 9 & 9 & 9 & 9 & 9 \\
\hline & Week $_{t+1}$ & 8 & 8 & 9 & 9 & 9 \\
\hline \multirow{2}{*}{ August $15^{\text {th }}$} & Week $_{t-1}$ & 0.25 & 0.09 & -0.35 & 0.00 & 0.00 \\
\hline & Week $_{t+1}$ & 0.40 & 0.84 & -0.01 & -0.14 & 0.27 \\
\hline \multirow{2}{*}{ Obs. } & Week $_{\mathrm{t}-1}$ & 8 & 9 & 9 & 9 & 9 \\
\hline & Week $_{t+1}$ & 6 & 5 & 5 & 9 & 6 \\
\hline \multirow{2}{*}{ Christmas } & Week $_{\mathrm{t}-1}$ & -0.42 & 0.03 & 0.06 & 0.23 & -0.03 \\
\hline & Week $_{t+1}$ & -0.50 & 0.44 & 0.47 & 0.25 & 0.17 \\
\hline \multirow{2}{*}{ Obs. } & Week $_{t-1}$ & 8 & 9 & 10 & 9 & 9 \\
\hline & Week $_{t+1}$ & 3 & 3 & 5 & 5 & 4 \\
\hline \multirow{2}{*}{ Holidays Mean } & Week $_{t-1}$ & -0.11 & 0.12 & 0.06 & 0.01 & 0.02 \\
\hline & Week $_{t+1}$ & 0.15 & 0.48 & 0.20 & 0.08 & 0.23 \\
\hline \multirow{2}{*}{ Obs. } & Week $_{t-1}$ & 8 & 9 & 9 & 9 & 9 \\
\hline & Week $_{t+1}$ & 6 & 5 & 6 & 8 & 6 \\
\hline $\mathrm{N}$ & & 116 & 112 & 114 & 102 & 111 \\
\hline \multicolumn{7}{|c|}{ Panel B: “Holidays” Risk } \\
\hline Holidays & Week & 2002 & 2003 & 2004 & 2005 & Period's Mean \\
\hline \multirow{2}{*}{ Easter } & Week $_{t-1}$ & 0.63 & 0.73 & 0.83 & 0.82 & 0.75 \\
\hline & Week $_{t+1}$ & 0.92 & 0.98 & 0.69 & 0.57 & 0.79 \\
\hline \multirow{2}{*}{ Obs. } & Week $_{t-1}$ & 9 & 9 & 9 & 9 & 9 \\
\hline & Week $_{t+1}$ & 8 & 8 & 9 & 9 & 9 \\
\hline \multirow{2}{*}{ August $15^{\text {th }}$} & Week $_{t-1}$ & 1.08 & 0.84 & 0.62 & 0.58 & 0.78 \\
\hline & Week $_{t+1}$ & 0.87 & 0.82 & 0.58 & 0.58 & 0.71 \\
\hline \multirow{2}{*}{ Obs. } & Week $_{t-1}$ & 8 & 9 & 9 & 9 & 9 \\
\hline & Week $_{t+1}$ & 6 & 5 & 5 & 9 & 6 \\
\hline \multirow{2}{*}{ Christmas } & Week $_{t-1}$ & 0.77 & 0.49 & 0.52 & 0.51 & 0.57 \\
\hline & Week $_{t+1}$ & 0.77 & 0.57 & 0.91 & 0.96 & 0.80 \\
\hline \multirow{2}{*}{ Obs. } & Week $_{t-1}$ & 8 & 9 & 10 & 9 & 9 \\
\hline & Week $_{t+1}$ & 3 & 3 & 5 & 5 & 4 \\
\hline \multirow{2}{*}{ Holidays Mean } & Week $_{t-1}$ & 0.83 & 0.69 & 0.66 & 0.64 & 0.71 \\
\hline & Week $_{t+1}$ & 0.85 & 0.79 & 0.73 & 0.70 & 0.77 \\
\hline \multirow{2}{*}{ Obs. } & Week $_{t-1}$ & 8 & 9 & 9 & 9 & 9 \\
\hline & Week $_{t+1}$ & 6 & 5 & 6 & 8 & 6 \\
\hline $\mathrm{N}$ & & 116 & 112 & 114 & 102 & 111 \\
\hline
\end{tabular}




\section{Table 8}

\section{T-tests on the "Holiday" Return Seasonality}

The table reports the average difference between the return in the weeks before and after holidays ( $t-1$ and $t+1$ respectively). The difference is calculated by subtracting the average return of week $t-1$ from the average return of week $t+1$. The statistical significance of the difference is examined via t-test applied on the difference between the average returns. Obs. refers to the number of observations and coincides with the number of funds available each year.

\begin{tabular}{lrrrr}
\hline Coefficients & $\mathbf{2 0 0 2}$ & $\mathbf{2 0 0 3}$ & $\mathbf{2 0 0 4}$ & $\mathbf{2 0 0 5}$ \\
\hline Difference in Easter Averages & $0.71^{*}$ & $-0.10^{*}$ & $-0.33^{*}$ & $0.35^{\star}$ \\
T-statistic & 13.95 & -4.05 & -16.59 & 26.65 \\
Obs. & 116 & 112 & 114 & 102 \\
Difference in August 15 Averages & $0.15^{\star}$ & $0.75^{*}$ & $0.34^{*}$ & $-0.14^{*}$ \\
T-statistic & 5.44 & 22.30 & 6.26 & -6.73 \\
Obs. & 116 & 112 & 114 & 102 \\
Difference in Christmas Averages & $-0.09^{* *}$ & $0.41^{*}$ & 0.41 & 0.02 \\
T-statistic & -2.29 & 11.80 & 1.38 & 0.11 \\
Obs. & 116 & 112 & 114 & 102 \\
Difference in Mean Holidays & & & & \\
Averages & $0.26^{*}$ & $0.35^{*}$ & 0.14 & 0.07 \\
T-statistic & 8.89 & 13.50 & 1.37 & 1.31 \\
Obs. & 116 & 112 & 114 & 102 \\
\hline
\end{tabular}

* Significant at the $1 \%$ level

** Significant at the $5 \%$ level 


\section{References}

Alexakis, Panagiotis and Manolis Xanthalis, 1995, "Day of the Week Effect on the Greek Stock Market", Applied Financial Economics 5, pp. 43-50.

Agathee, Ushad Subadar, 2008, "Day of the Week Effects: Evidence from the Stock Exchange of Mauritius", International Research Journal of Finance and Economics 17, pp. 7-14.

Aggarwal, Raj, Ramesh P. Rao, and Takto Hiraki, 1990, "Regularities in Tokyo Stock Exchange Security Returns: P/E, Size, and Seasonal Influences", Journal of Financial Research 13, pp. 249-263.

Ariel, Robert A., 1987, “A Monthly Effect in Stock Returns”, Journal of Financial Economics 18, pp. 161-174.

Ariel, Robert A., 1990, "High Stock Returns Before Holidays: Existence and Evidence on Possible Causes", Journal of Finance 45 (5), pp. 1611-1626.

Bhabra, Harjeet S., Upinder S. Dhillon, and Gabriel G. Ramirez, 1999, "A November Effect? Revisiting the Tax-Loss-Selling Hypothesis", Financial Management 28 (4). Pp. 5-15.

Bodla, B.S. and J.J. Kiran, 2006, "Monthly Effects in Stock Returns: New Evidence from the Indian Stock Market", ICFAI Journal of Applied Finance 12 (7), pp. 5-13.

Boudreaux, Denis O., 1995, "The Monthly Effect in International Stock Markets: Evidence and Implications", Journal of Financial and Strategic Decisions 8 (1), pp. 15-20.

Cadsby, Charles B. and Mitchell Ratner, 1992, "Turn-of-the-Month and Pre-Holiday Effects on Stock Returns: Some International Evidence", Journal of Banking and Finance 16 (3), pp. 497-509.

Chen, Honghui and Vijay Singal, 2003, "A December Effect with Tax-Gain Selling”, Financial Analyst Journal 59 (4), pp. 78-90.

Chukwuogor, Chiaku, 2008, “An Econometric Analysis of African Stock Market: Annual Returns Analysis, Day-of-the-Week Effect and Volatility of Returns, International Research Journal of Finance and Economics 14, pp. 370-378.

Coutts, J Andrew, Christos Kaplanidis and Jennifer Roberts, 2000, "Security Price Anomalies in an Emerging Market: The Case of the Athens Stock Exchange" Applied Financial Economics 10 (5), pp. 561-71.

Dancy, Joseph, 2007, “Stock Market Seasonality- Historical Data, Trends \& Market Timing”, Global Stock Markets (22 November 2007).

D’Mello, Ranjan, Stephen Ferris, and Chuan Yang Hwang, 2003, “The Tax-Loss Selling Hypothesis, Market Liquidity, and Price Pressure around the Turn-of-the-Year", Journal of Financial Markets 6 (1), pp. 73-98.

Floros, Christos, 2008, "The Monthly and Trading Month Effects in Greek Stock Market Returns: 1996-2002”, Managerial Finance 34 (7), pp. 453-464.

French, Kenneth 1980, "Stock Returns and the Weekend Effect”, Journal of Financial Economics 8, pp. 55-69.

Gibbons, Michael R. and Patrick Hess, 1981, "Day of the Week Effects and Asset Returns", Journal of Business 54 (4), 579-596.

Gibson, Scott, Assem Safieddine, and Sheridan Titman, 2000, "Tax-Motivated Trading and Price Pressure: An Analysis of Mutual Fund Holdings", Journal of Financial and Quantitative Analysis 35 (3), pp. 369-386. 
Hakan, Berument and Halil Kiymaz, 2001, "The Day of the Week Effect on Stock Market Volatility, Journal of Economics and Finance 25 (2), pp. 181-193.

Haug, Mark and Mark Hirschey, 2006, "The January Effect", Financial Analyst Journal 62 (5), pp. 78-88.

Haugen, Robert A. and Josef Lakonishok, 1988, “The Incredible January Effect”, Homewood: Dow Jones-Irwin.

Hui, T.K., 2005, "Day-of-the-week Effects in US and Asian-Pacific Stock Markets during the Asian Financial Crisis: A Non-parametric Test", International Journal of Management Science 33 , pp. 277-282.

Jaffe, Jeffery and Randolph Westerfield, 1985, "The Week-End Effect in Common Stock Returns: The International Evidence", Journal of Finance 40, pp. 433-454.

Keim, Donald B., 1983, "Size-Related Anomalies and Stock Return Seasonality: Further Empirical Evidence", Journal of Financial Economics 12, pp. 13-32.

Keim, Donald B. and Robert F. Stambaugh, 1984, "A Further Investigation of the Weekend Effect in Stock Returns”, Journal of Finance 39 (3), pp. 819-835.

Kenourgios, Dimitris and Aristeidis Samitas, 2008, "The Day of the Week Patterns on Stock Market Return and Volatility: Evidence for the Athens Stock Exchange", International Research Journal of Finance and Economics 15, pp. 78-89.

Kim, Chan W. and Jinwoo Park, 1994, "Holiday Effects and Stock Returns: Further Evidence", Journal of Financial and Quantitative Analysis 29 (1), pp. 145-157.

Kohers, G., N. Kohers, V. Pandey and T. Kohers, 2004, "The Disappearing Day-of-the-week effect in the World's Largest Equity Markets", Applied Economic Letters 11, pp.167-171.

Lakonishok, Josef, Andrei Shleifer, Richard Thaler, and Robert Vishny, 1991, "Window Dressing by Pension Fund Managers", American Economic Review 81 (2), pp. 227-231.

Lakonishok, Josef and Seymour Smidt, 1984, "Volume and Turn-of-the-Year Behavior", Journal of Financial Economics 13 (3), pp. 435-455.

Lakonishok, Josef and Seymour Smidt, 1988, “Are Seasonal Anomalies Real? A Ninety-Year Perspective”, Review of Financial Studies 1 (4), pp. 403-425.

Milonas, Nikolaos and Gerasimos Rompotis, "Seasonality in ETFs' Risk and Return: The November Effect”, (2008), EFMA Annual Meetings, Athens, Greece.

Mills T., C. Siriopoulos, R. Markellos and D. Harizanis, 2000, "Seasonality in the Athens Stock Exchange", Applied Financial Economics 10, pp. 137-42.

Reinganum, Marc R., 1983, “The Anomalous Stock Market Behavior of Small Firms in January”, Journal of Financial Economics 12, pp. 89-104.

Ritter, Jay R., 1988, “The Buying and Selling Behavior of Individual Investors at the Turn of the Year", Journal of Finance 43 (3), pp. 701-719.

Roll, Richard, 1983, "Vas Ist Das? The Turn of the Year Effect and the Return Premia of Small Firms", Journal of Portfolio Management 9 (2), pp. 18-28.

Rozeff, Michael S. and William R. Kinney, 1976, "Capital Market Seasonality: The Case of Stock Market Returns”, Journal of Financial Economics 3, pp. 376-402.

Smirlock, Michael and Laura Starks, 1986, "Day of the Week and Intraday Effects in Stock Returns", Journal of Financial Economics 17, pp. 197-210. 
Starks, Laura T., Li Yong and Lu Zheng, 2006, "Tax-Loss Selling and the January Effect: Evidence from Municipal Bond Closed-end Funds", Journal of Finance 61 (6) pp. 3049-3067.

Steeley, J.M., 2001, “A Note on Information Seasonality and the Disappearance of the Weekend Effect in the UK Stock Market", Journal of Banking and Finance 25, pp. 1941-1956.

Tsangarakis, Nickolaos, 2007, "The day-of-the-week effect in the Athens Stock Exchange", Applied Financial Economics 17, pp. 1447-1454.

Yakob, Noor Azuddin., Diana. Beal and Sarath Delpachitra, 2005, "Seasonality in the Asia Pacific Stock Markets", Journal of Assets Management 6, pp. 298-318. 